\title{
Ritual eller strategi - upphandlingar och ramavtal inom den sociala ungdomsvården
}

\author{
TORBJÖRN FORKBY \& STAFFAN HÖJER
}

\begin{abstract}
Mer än hälften av Sveriges kommuner har upphandlat ramavtal för att styra den sociala ungdomsvården. I denna artikel undersöks attityderna till dessa samt på vilka grunder avsteg görs från de ingångna avtalen.
\end{abstract}

En betydande del av institutionsvården av barn och ungdomar i Sverige bedrivs av externa och privata vårdgivare. Kostnaderna för institutionsvården totalt har ökat sedan 90-talet och uppgår idag till drygt fyra miljarder per år vilket är mer än en tredjedel av den totala kostnaden för den sociala barnoch ungdomsvården (Socialstyrelsen 2007a). Under senare år har utöver kostnaderna även kvaliteten på och effekterna av institutionsvården ifrågasatts. Inom välfärdssystemen har ett marknadstänkande, där effektivitet, kvalitet och mätbarhet poängteras, fått ett genomslag. På flera håll har det medfört radikala organisationsförändringar,

Torbjörn Forkby, fil. dr, institutionen för socialt arbete, Göteborgs universitet

Staffan Höjer, docent i socialt arbete, institutionen för socialt arbete, Göteborgs universitet som t.ex. beställare-utförare organisationer (Montin 1996, Wiklund 2006). Det är därför naturligt att olika styrningsformer för institutionsvården utvecklas. I denna artikel undersöks vilken betydelse ramavtal har som styrningsinstrument för att vägleda ett rationellt beslutsfattande.

Styrningssträvanden kan uttryckas i ekonomiska, administrativa och professionella termer, men utgår från en gemensam önskan om rationalitet $i$ beslutsfattande och genomförande (Brunsson 2006b). Införandet av ramavtal kan ses som ett sätt att öka rationaliteten i kommunernas hantering av den köpta vården. En ökad rationalitet och »ordning och reda» kan också förväntas höja legitimiteten för en ifrågasatt vårdform.

Tanken är att hänsyn till både ekonomiska faktorer och vårdens innehåll skall tas när ramavtal upprättas. Lag (1992:1528) 
om offentlig upphandling slår fast att det ekonomiskt mest fördelaktiga alternativet skall väljas. Samtidigt betonar Socialtjänstlagen (2001:453) den unges behov och kommunens skyldighet att verka i enlighet med barnens bästa. Det finns idag ingen samlad kunskap om vilken roll dessa ramavtal spelar för vare sig pris eller kvalitet. Det finns heller ingen diskussion om deras legitimerande funktion.

Syftet med denna artikel är att beskriva och analysera upphandlingar samt betydelsen av ramavtal inom den sociala barnavården för tonåringar. ${ }^{1} \mathrm{Av}$ särskilt intresse är att studera hur de individuella behovsorienterade principer som enligt Socialtjänstlagen kännetecknar den sociala barnavården, påverkas av avsikterna att generellt reglera denna marknad. Speciellt kommer följande frågeställningar att studeras:

- Hur många kommuner har ramavtal och vad innehåller de avtal som slutits för den sociala ungdomsvården?

- Vilka uppfattningar om upphandlingar och ramavtal finns bland verksamhetsansvariga inom kommunernas individoch familjeomsorg?

- I vilken utsträckning följs ramavtalen inom den sociala ungdomsvården?

\section{Tidigare forskning}

Vissa förhållanden är kända vad gäller den

1 Artikeln ingår som en del av forskningsprojektet „Köpt vård - villkor, aktörer och köpprocesser på den sociala barnavårdens marknad." (FAS 2005-0938) köpta vården. Den officiella statistiken innefattar sådant som hur många som placeras och längden på placeringar. Sålunda var 9.300 ungdomar mellan 13-17 år placerade för vård utom hemmet någon gång under 2006, varav 2.900 var placerade på institution och resterande 6.400 i familjehem. Dessutom deltog 4.200 i strukturerade öppenvårdsprogram under året (Socialstyrelsen 2007b). Tonåringar dominerar antalet placeringar i dygnsvård. Antalet ungdomar som placeras $\mathrm{i}$ institutionsvård har legat relativt konstant de senaste åren men ökade under 1990-talet, både om man ser till antalet och andelen som placerades (Lundström \& Vinnerljung 2001). Det har dessutom skett en kostnadsökning inom institutionsvården som inleddes samtidigt som privata aktörer dök upp inom institutionsvården i större omfattning (Sallnäs 2005).

De flesta barnavårdsinstitutionerna bedrivs i enskild regi där de anställdas andel med vårdprofessionell utbildning är låg (Sallnäs 2000, Socialstyrelsen 2006). Kunskap om effekter av olika behandlingsformer börjar växa fram, även om åtskilligt mer finns att göra (se t.ex. Andreassen 2003, Levin 1998, Lipsey 1995).

Det finns ett flertal socialpolitiskt orienterade studier som behandlar ett nytt slags kontraktskultur, det vill säga statens ökande tendens att se andra aktörer som verkställare av politiska beslut, inte minst i USA (Selle 1996, Salomon 2002, Hasenfeld \& Powell 2004), men även svenska studier finns (t.ex. Lundström \& Svedberg 1998). En aktuell förvaltningsekonomisk studie söker förklaringar på varför marknadslösningar väljs i svenska kommuner 
(Johansson 2006). Det finns också forskning som undersöker effekter av införandet av modeller som bygger på beställar-utförar-system inom engelsk social barnavård (Kirkpatrick et al. 1999). De sistnämnda kritiserar bland annat den förändrade socialarbetarroll sådana system medför där socialarbetarna utvecklas till "care managers« med framförallt utredande och upphandlande uppgifter. I en studie analyseras socialarbetares olika syn på kontraktets betydelse i praktiskt arbete (Fargion 2003). Marknadsorienterade sätt att styra genom delad beställar-utförarorganisation inom den svenska socialtjänsten har också kritiserats för att dåligt tillgodose svaga klienter med komplexa behov och problem (Blom 1998).

Studier om upphandlingar av ramavtal inom vård och omsorg är mer sällsynta. Några undantag är Noréns (2003) studie av kundvalsmarknader inom skola och omsorg samt Berlins (2006) om beställarstyrning inom sjukvården. Studier av enskilda upphandlingar förekommer också $\mathrm{i}$ form av mindre utvärderingar och sällan med några generaliseringsanspråk (t.ex. Ohlsson 2007).

\section{Marknader, marknadsorientering och "New Public Management"}

New Public Management (NPM) kan ses som en samlande beteckning för nya styrformer av offentlig verksamhet som fick genomslag i stora delar av västvärlden under 90-talet (Pollitt \& Bouckaert 2000). En utgångspunkt för NPM är önskan att styra offentlig verksamhet med hjälp av marknadsprinciper. Idén är att uppnå effektivisering genom målstyrning, konkurrens, preciserade uppföljningssystem och valfrihet (Almqvist 2006).

Offentliga upphandlingar är reglerade såväl på EU som nationell nivå. Marknadsdesigners översätter dessa lagstiftningskrav till konkreta regler och procedurer. I vårt fall finns sådana designers genom särskilda upphandlingsorganisationer eller personer som utformar och genomför upphandlingar av ramavtal. Callon (1998) menar att det är möjligt att inhägna en marknad förutsatt att den just designas på rätt sätt. Det handlar om att prioritera vilka alternativ som är mest önskvärda och kalkylera hur dessa skall uppnås, alltså att bestämma de institutionella förutsättningarna för marknaden. Möjligheten till sanktion är viktig för att upprätthålla en fungerande (designad) marknad. Såväl beställare som utförare måste kunna klaga eller utnyttja en sanktionsmöjlighet, t.ex. genom ekonomisk kompensation, om en aktör inte håller sig inom ramarna (Norén 2003).

Andra är mer skeptiska än Callon och pekar på en mängd problem som finns med att få en beställarmarknad att fungera. Marknadsmodellen kritiseras för att bygga på orealistiska beteendeantaganden. En kund förväntas vara otrogen, stark, faktasökande och sträva efter att i första hand maximera sin egen nytta. I själva verket visar det sig att kunderna är relativt svaga, ganska trogna sina tidigare affärsrelationer och inte särskilt faktasökande (Berlin 2006). Beställaren har också svårt att precisera vilken typ av vård som skall beställas. Det är inte alltid lätt att säga vilka behov som

Torbjörn Forkby \& Staffan Höjer: Ritual eller strategi - upphandlingar... 
finns och ibland kan detta till och med vara en del av insatsen (som vid utredningsplaceringar). Därtill finns avvägningsproblem som har att göra med relationen mellan kvantitet och kvalitet. I vårt fall handlar det framförallt om hur mycket ekonomiperspektivet skall betonas i förhållande till andra perspektiv (administrativa, professionella) och olika kvalitetskrav. Det finns heller knappast någon regelmässig marknad där insatser kan jämföras och konkurrera. Lågbeställarkompetens anses också vara ett problem som dels har att göra med ovana vid att hantera marknadsrelationer och dels går tillbaka på svårdefinierbara behov och därmed otydliga kravspecifikationer.

På denna form av marknad har det också visat sig att utbud och efterfrågan inte följer ordinarie mönster. Snarare kan utbudet av vissa tjänster skapa sin egen efterfrågan (Berlin 2006). Inom den sociala barnavården kan paralleller dras till tiden då de nya privata HVB hemmen snabbt började byggas ut (Sallnäs 2005).

Även om NPM och marknadssättning syftar till effektivisering och kostnadsreducering kan det i praktiken innebära ökade kostnader. Att använda marknaden för att reglera priset på en vara eller tjänst är inte gratis, utan transaktionskostnader uppstår såväl före köpet för att bestämma kvalitetskriterier, som efter för att kontrollera att varan eller tjänsten motsvarar kraven. Kostnader uppstår bl.a. för att upprätthålla särskilda upphandlingsorganisationer, och även i form av tid som avsätts för att hantera vårdköpen. I vissa fall är kostnaderna till och med så höga att det ekonomiska utfallet blir negativt av en marknadslösning jämfört med egenproduktion (Johansson
2006, Williamson 1996). Köpta vårdtjänster är exempel på svårstyrbara tjänster. De köps in relativt sällan och har hög specificitet i det att de bör individanpassas och justeringar kan behöva göras kontinuerligt inom ramen för avtalet. Detta gör att omfattningen av varje insatsform blir för liten för att kompetensen ska kunna byggas upp inom den egna organisationen, samtidigt är de så komplexa att de kräver ett nära samarbete mellan beställare och utförare. Hybridformer mellan marknadslösningar och egenproduktionen kan därför ses för dessa typer av tjänster.

I socialt arbete råder en genuin osäkerhet om olika handlingsstrategiers effekter. Styrningen får istället ske genom att mindre rationella metoder tillämpas där socialarbetarna verkar under löst sammanhållna former och under förhållanden som präglas av osäkerhet. ${ }^{2}$ Det blir då svårt för huvudmannen (ledningen för socialtjänsten eller kommunen) att med administrativa verktyg styra verksamheten. Ouchi (1977) menar att sådana verksamheter där de styrande inte har kunskap om vare sig lämpligt beteende (handlingsstrategi) eller vilket resultat som ska uppnås styrs rituellt. Man styr med hjälp av värderingar och antaganden om vad man hoppas uppnå, i allianser som man litar på och efter rutiner man vant sig vid.

I den sociala ungdomsvården blandas alltså olika styrlogiker. När liknande pro-

2 Jämför Hasenfeld (1983) och Lipsky (1980) om gatuplansbyråkrater och deras förmåga att använda sin professionella diskretion under löst organiserade former, samt Evans \& Harris (2004) diskussion om diskretionens ställning i dagens sociala arbete. 
blem dryftas i statsvetenskaplig forskning brukar det handla om en blandning av demokratiska och marknadslika styrlogiker. I den förra fokuseras värden som rättsäkerhet, yttrandefrihet och medbestämmande medan marknadslogiken snarare betonar effektivitet och produktivitet. Professionsforskaren Freidson (2001) preciserar och problematiserar kollisionerna mellan olika styrlogiker när han utöver marknadslogiken diskuterar en byråkratisk och en professionell logik. Den byråkratiska betonar framför allt regler, rutiner och formfrågor medan den professionella logiken utgår från yrkeskunskaper och värderingar grundade i forskning och beprövad erfarenhet. När det handlar om köpt social ungdomsvård är det främst de professionellas analys av ungdomars behov och ramavtalens regler och marknadsinriktning som kolliderar.

\section{Material och metoder}

Avsikten med studien är att göra jämförelser på kommunnivå av hur villkoren för den köpta vården för ungdomar, 13-18 år, ser ut. Vi har särskilt intresserat oss för i vilken mån olika kommuner har slutit ramavtal för ungdomsvården eller inte, vad ramavtalen innehåller, hur upphandlingarna har gått till, erfarenheter av upphandlingsprocesser samt $\mathrm{i}$ vilken mån de enskilda vårdköpen följer ingångna ramavtal.

Vi har använt oss av två metoder och tre material. För det första har vi genomfört en totalstudie där en representant för den sociala barnavården $\mathrm{i}$ Sveriges samtliga kommuner telefonintervjuats om ramavtal och köpt vård (på stadsdelsnivå i Stockholm,
Göteborg och Malmö). Totalt genomfördes 336 telefonintervjuer. För det andra har vi med hjälp av en speciell datatjänst "OPIC" gjort innehållsanalyser av offentliga underlag för ramavtal som träffats av Sveriges kommuner. Bland datatjänstens uppgifter om upphandlingar studerades 59 som gäller upphandlade ramavtal för social barnavård riktade till tonåringar. För det tredje har vi med hjälp av offentlig statistik sammanställt sekundärdata om Sveriges kommuner för att kunna göra olika typer av jämförelser med våra andra datamaterial.

\section{Intervjustudien}

Ett strukturerat intervjuunderlag användes vid telefonintervjuerna. Vissa frågor var avsedda att fånga de faktiska förhållandena i kommunen (t.ex. förekomst av ramavtal), andra avsåg att fånga inställningen till och praktiskt arbete med ramavtal. Bivariata analyser har genomförts med hjälp av SPSS. Vid sidan av svaren på de fasta svarsalternativen har respondenternas kommentarer noterats och skrivits ut i sin helhet. Därefter har dessa analyserats med hjälp av meningskoncentrering där såväl gemensamma som avvikande teman noterats för att bistå vid tolkning och analys av studiens utfall (Kvale 1997).

Tre frågor är av särskilt intresse för studiens validitet och reliabilitet. Den första handlar om vem som intervjuats $i$ kommunerna. Vi har sökt efter personer i chefsställning med god överblick över den köpta vården, men som inte själva handlägger utredningar. I de flesta kommuner har detta varit antingen chefen för individ- och familjeomsorgen eller en underställd chef 
med ansvar för ungdomsvården. I små kommuner har vi intervjuat socialchefen som har motsvarande uppgifter.

Den andra frågan är hur vi faktiskt genomförde studien för att behälla konstans $i$ bedömningar av svar, över tid och mellan olika intervjuare. Telefonintervjuerna genomfördes under hösten 2006. De flesta intervjuer har genomförts av en projektanställd med magisterutbildning i socialt arbete och god kännedom om den kommunala barnavården. Även artikelförfattarna har genomfört ett antal intervjuer såväl under tiden för utarbetandet av intervjuunderlaget som under den faktiska studien. Regelbundet har spörsmål som har med insamling och kodning av svar diskuterats i forskargruppen. Dubbelkodningar har genomförts av några variabler.

Den tredje frågan handlar om graden av social önskvärdhet som àterspeglas $i$ intervjupersonernas svar. Eftersom frågor om köpt vård har kopplingar till lagstiftning och regler som bestämmer hur praktiken skall vara, och samtidigt innehåller professionella element och bedömningar som återspeglar hur praktiken bör vara finns naturligtvis en risk för social önskvärdhet eller politisk korrekthet. I vissa avseenden är det just sådana attityder och värderingar som vi önskar fånga, till exempel när vi ställer ett antal attitydfrågor kopplade till den köpta vården och användandet av ramavtal för denna. I andra frågor, såsom i vilken mån praktik och policy överensstämmer, kan man förvänta sig en viss övervärdering av hur det borde vara. Detta skulle innebära att praktik och policy överensstämmer, åtminstone i de fall där man är positiv till de ramavtal som slutits. Som framgår i studien förekommer dock stora differenser just på dessa punkter, vilket blir extra intressant för analysen.

\section{OPIC}

För att säljare av varor och tjänster ska kunna ge anbud annonseras offentliga upphandlingar på flera sätt. Här finns tydliga lagstiftningsdirektiv. I och med den mängd upphandlingar som sker kan det dock vara svårt för säljarna att hålla sig à jour med marknaden. Tjänster har därför utvecklats som erbjuder kontinuerlig omvärldsbevakning, varav OPIC är en. Detta är en privat tjänst som säljs via abonnemang (ett sådant tecknades för studien). Enligt företagets egen kontroll har tjänsten en fullständig marknadstäckning inom socialtjänstområdet sedan år 2000. För vårt vidkommande har tjänsten fördelen att den tillhandahåller all dokumentation som upprättats i samband med upphandlingen, vilket gav möjlighet till mer detaljerade analyser.

\section{Ramavtal}

I lagen om offentlig upphandling av varor och tjänster identifieras tre sätt att köpa (socialvårds)tjänster: förenklad upphandling, urvalsupphandling och direktupphandling. Enbart de två första innehåller en upphandlingsprocess där tjänsten beskrivs och krav specificeras.

Enligt huvudregeln om affärsmässighet ska upphandling göras så att konkurrensmöjligheter utnyttjas och att upphandlingsprocessen sker utan ovidkommande hänsyn. Upphandlingarna av barnavårds- 
tjänster har i huvudsak avsett institutionsvård men ibland även öppenvård. Vanligen avslutas upphandlingarna med att ett ramavtal tecknas med ett antal vårdgivare. Beställningar av tjänster från en vårdgivare inom ramavtalet "avropas» därefter enligt ramavtalet. I de fall varans eller tjänstens värde är lågt eller om det finns synnerliga skäl, får direktupphandling ske.

Anbud kan vid en upphandling antas efter två principer: det ekonomiskt mest fördelaktiga eller det lägsta priset. I det ekonomiskt mest fördelaktiga ligger möjligheten att ta hänsyn till fler aspekter än priset, t.ex. leveranstid, driftskostnader, kvalitet, estetiska, funktionella och tekniska egenskaper. Vid upphandlingen ska de faktorer som tillmäts betydelse anges och även helst hur de värderas sinsemellan.

Direktupphandling sker utan att tjänsten beskrivs, anbud infordras och värderas, alltså inköpen sker direkt "över disk». Det är direktupphandlingar som sker när socialtjänsten för att sluta ett individuellt placeringsavtal direkt kontaktar och förhandlar med en institution som man inte har ramavtal med.

\section{Förekomst och upphandlingsformer}

Hösten 2006 hade 181 av landets 290 kommuner (62 procent) ramavtal som inbegrep vård och behandling av ungdomar. Knappt två tredjedelar av dem som hade ramavtal hade haft sådana under fyra år eller mer. Den vanligaste avtalstiden löpte på tre år fördelat på två år i grundavtal med möjlighet till ett års förlängning.
Upphandlingarna genomfördes oftast genom att en referensgrupp bildades (marknadens designers). Denna grupp leddes vid i princip samtliga upphandlingar av en specialiserad upphandlingsfunktion. I vissa kommuner var detta en person från ett upphandlingsbolag eller liknande större fristående organisation, i mindre kommuner en person med särskilt uppdrag. Arbetsledare eller chefer inom socialtjänsten ingick i 70 procent av upphandlingarna. I omkring en fjärdedel av fallen hade socialsekretare också ingått i processen i något skede. Däremot deltog mycket få politiker eller fackföreningsrepresentanter i arbetet och $i$ inget fall hade någon klientorganisation ingått $\mathrm{i}$ en arbetsgrupp eller tillfrågats om synpunkter i något skede av processen.

Under perioden 2000 fram till september 2006 genomfördes enligt OPIC 59 upphandlingar av ramavtal för socialvårdstjänster för ungdomar i Sverige. 24 av dessa genomfördes av en enskild kommun och de andra av flera kommuner i samverkan.

Att det är fråga om komplexa tjänster med svårbedömd kvalitet kan man konstatera när man ser till den variation som finns av bedömnings- och värderingsformer för att rangordna vårdgivares kvalitet. En kategorisering av 49 av de 59 upphandlingarna visade att 18 upphandlingar enbart beskriver grundläggande information som skulle tillmätas betydelse vid en värdering, såsom personalens kompetens, förmåga och förutsättningar till att motsvara behovet, geografiskt läge och så vidare. ${ }^{3}$ Nästa nivå är mer utvecklad och består av tolv upphandlingar

3 Uppgifter om värderingsprocessen saknades för tio av upphandlingarna.

Torbjörn Forkby \& Staffan Höjer: Ritual eller strategi - upphandlingar.. 
där man förutom att ange vad som kommer att tillmätas betydelse också redovisat någon form av viktning eller grov andelsprecisering för de olika värderingskriterierna. Man kan exempelvis ange att kvalitetskriterier värderas till 50 procent i förhållande till priset, och vad som avses med kvalitetskriterierna. Den tredje kategorin representeras av 19 upphandlingar som beskriver relativt avancerade beräkningssystem. Värderingsprocessen bryts ned till att ett antal delområden som betygssätts var och en och därefter vägs samman. Beräkningssystemen tenderar av materialet att döma bli mer avancerade och tydligare över tid. Priset verkar på samma sätt tillmätas en större vikt.

25 av de 59 förfrågningsunderlagen innehåller en specifikation av hur priset skall värderas i förhållande till kvaliteten. Spridningen $i$ viktningarna ger en intressant inblick i hur svårt det kan vara att avgöra pris i förhållande till kvalitet för att finna det ekonomiskt mest fördelaktiga alternativet. I flera förfrågningsunderlag markeras att kvaliteten är viktigare än priset. Dessa vill uppenbarligen tona ned att pris skall vara ett konkurrensmedel i detta verksamhetsområde. De som tilldelar priset lägst betydelse viktar det till 30 procent i förhållande till övrigt. Tolv av 25 värderar priset till lägre än hälften av bedömningsgrunden. Nio uppger att pris och övriga faktorer viktas lika, tre viktar priset till 70 procent medan man $i$ en upphandling menar att priset är till 100 procent avgörande.

\section{Ramavtal - praktiska men bra?}

Det påstående som flest kommunrepre- sentanter, åtta av tio, instämmer i är att ramavtal underlättar praktisk administration vid vårdköp (se Tabell 1). Fler än sju av tio menar att placeringsavtalen blir mer genomarbetade. I första hand betonas alltså ramavtalens administrativa sida, att de strukturerar och formaliserar köpprocessen.

En majoritet av de tillfrågade menar också att ramavtalen innebär en kvalitetshöjning, samtidigt som genomskinligheten ökar - man vet bättre vad man får för pengarna. Arbetet med ramavtalet innebär en sådan genomlysning av vårdgivarna att det ses som en del av ett kvalitetssäkringsarbete. Samtidigt är det många som kommenterar att det är mycket svårt att värdera och garantera kvaliteten i denna typ av tjänst eftersom kommunen har en begränsad insyn i vad som egentligen händer innanför institutionens väggar. Vårdens kvalitet varierar också över tid då den är avhängig förhållanden som ledningsförmåga, de anställdas personliga lämplighet och sammansättning av ungdomsgruppen. Institutionsvård betecknas som en osäker färskvara som byter innehåll och kvalitet exempelvis i förhållande till personalbyten och metodval.

Ramavtalens legitimerande och rituella karaktär belyses också då några hävdade att ramavtalet framförallt var viktigt innan det var slutet, sedan spelar det inte så stor roll längre. En anledning till att genomföra upphandlingar skulle kunna vara att stimulera till konkurrens mellan olika vårdgivare så att skattemedlen används så effektivt som möjligt. Det finns emellertid en stor tveksamhet bland de kommunala tjänstemännen när det gäller ramavtalens 
inverkan på kostnaderna. Drygt hälften menar att ramavtal innebär att vården blir billigare, medan en knapp femtedel anser att vårdkostnaden blir dyrare. Många kommenterade att priset inte påverkas alls av upphandlingen i och med att det knappast råder någon konkurrens inom denna del av ungdomsvården. På denna punkt påpekar flera att det är stora skillnader jämfört med vuxenvården, där viss priskonkurrens faktiskt anses råda. Inom ungdomsvården är kommunerna på ett annat sätt hänvisade till att använda sig av de erbjudna platserna, i den mån det finns några tillgängliga. Bristen på platser gör alltså att konkurrensen är låg. Till detta kommer att man inom barnavården är ovan vid förhandlingar och vid att "tala pengar».

Den grupp som menar att upphandlingen, tvärtemot intentionerna, har höjt prisnivån på platserna anför två argument. För det första att de högre kraven på kvalitet som upphandlingsprocessen medfört exempelvis vad gäller bemanning, vetenskapligt grundade metoder och uppföljning, direkt återspeglats i en högre vårdavgift. För det andra att upphandlingen är en stor administrativ process som både kostar tid och pengar (transaktionskostnader). Den är för stor menar många av dem som arbetar i mindre kommuner och som saknar personer med upphandlingskompetens. I en av storstadskommunerna lägger upphandlingsorganisationen en procentuell avgift på priset som direkt höjer dygnskostnaden.

Tre påståenden i telefonintervjuerna avser ramavtalens styrande effekt på vad man köper och hur man faktiskt går tillväga. Omkring hälften menar att ramavtalen innebär att man får ett alltför begränsat utbud av vårdgivare att välja mellan. Denna uppfattning är särskilt framträdande bland mindre kommuner och från regioner där man inte har så stor tillgång till institutioner överhuvudtaget. En något mindre grupp, drygt 40 procent, menar att ramavtalen endast har en mer begränsad roll för vilka vårdköp som görs. Den dryga tredjedel som menar att flexibiliteten minskar om man har ramavtal, menar att dessa avtal innebär en så stor begränsning av vårdutbudet att det försvårar den individuella anpassningen.

\section{Skillnader mellan de som har och de som inte har}

Det visar sig att det finns signifikanta skillnader mellan de som har och de som inte har ramavtal för sex av de efterfrågade tio variablerna. ${ }^{4}$ När det handlar om frågor som rör administrativa aspekter om ramavtal är dock skillnaderna små, de flesta är övertygade om ramavtalens fördelar i administrativt hänseende. Grupperna skiljer sig mest åt i synsättet på om ramavtal innebär en ökad kvalitet i vården. Kvalitetsfrågan kan förväntas spela en stor roll när det handlar om socialtjänstens insatser. Bland de som har ramavtal finns en klar uppfattning om att kvaliteten på vården påverkas positivt av ramavtalet och upphandlingsprocessen. Huruvida inställningen har påverkat

4 Extra försiktighet $\mathrm{i}$ tolkning av data påpekas då de som ej har ramavtal uttalar sig utifrån föreställningen att ha ett sådant, medan övriga kan yttra sig om erfarenheterna från ramavtal. 
dessa kommuner att delta i upphandlingar, eller om attityden speglar hur kvaliteten i vården upplevs när man har respektive inte har ramavtal, kan vi dock i nuläget inte säga något om.

Man kan också finna ett antal andra frågor där de som inte har ramavtal är mera tveksamma till ramavtal. De menar att vårdutbudet begränsas, att flexibiliteten minskar och därmed att den individuella matchningen försvåras. De som inte har ramavtal menar också att ramavtal endast har liten betydelse för vårdköpen. En tolkning, med hänsyn till det kvalitativa materialet, är att uppfattningar om att ramavtalen faktiskt anses kunna försvåra arbetet genom att begränsa och minska flexibilitet, sannolikt fungerar som motstånd mot att ramavtal införs.

Det finns signifikanta skillnader för många av påståendena som indikerar en mer negativ inställning till ramavtalen ju längre tid man haft sådana (ej i Tabell). Bland de som haft ramavtal tre år eller längre menade t.ex. 44 procent att ramavtal endast hade en begränsad roll vid vårdköpen jämfört med 23 procent bland de med nya ramavtal.

\section{Att följa ramavtalet eller inte- en fråga om policy och praktik}

Syftet med ramavtalen är bland annat att

\section{Tabell I.}

Andel som instämmer i olikapåståenden om ramavtalbland centrala aktörer inom socialtjänstens barnavård i Sveriges kommuner och kommundelar (Stockholm, Göteborg och Malmö). $\mathrm{N}=336$. Fördelat efter förekomst av ramavtal och rangordnade enligt grad av instämmanden.

\begin{tabular}{|c|c|c|c|c|}
\hline & \multicolumn{2}{|c|}{ Totalt } & $\begin{array}{l}\text { Har ram- } \\
\text { avtal }\end{array}$ & $\begin{array}{l}\text { Saknar } \\
\text { ramavtal }\end{array}$ \\
\hline Påstående:(Jag anser att ramavtal:) & & & $\begin{array}{l}\text { Instämmer } \\
\text { helt/delvis }\end{array}$ & $\begin{array}{l}\text { Instämmer } \\
\text { helt/delvis }\end{array}$ \\
\hline I. Underlättar praktisk administration vid vårdköp & 81,0 & n.s. & 82,8 & 77,1 \\
\hline 2. Placeringsavtal mer genomarbetade & 72,6 & ***** & 78,4 & 60,6 \\
\hline 3. Leder till att vi vet vad vi får för pengarna & 72,0 & n.s. & 74,4 & 67,0 \\
\hline 4. Ger högre kvalitet i vården & 63,9 & **** & 76,1 & 38,5 \\
\hline 5. Ger billigare vård & 56,0 & n.s. & 53,3 & 61,5 \\
\hline 6. Ger ett för begränsat vårdutbud & 51,8 & **** & 41,9 & 72,5 \\
\hline 7. Endast har begränsad roll vid vårdköp & 42,9 & **** & 37,9 & 53,2 \\
\hline $\begin{array}{l}\text { 8. Innebär att insatserna blir för definierade. Flexi- } \\
\text { biliteten minskar. }\end{array}$ & 35,7 & **** & 26,9 & 54,1 \\
\hline 9. Ger dyrare vård & 17,6 & n.s. & 18,6 & 15,6 \\
\hline 10. Skrivande av placeringsavtal tar för lång tid & 6,3 & **** & 4,4 & 10,2 \\
\hline
\end{tabular}

Signifikansnivå (p). ${ }^{* * *} \mathrm{p} \leq 0.001,{ }^{* *} \mathrm{p} \leq 0,01,{ }^{*} \mathrm{p} \leq 0,05$, n.s. $=$ ej signifikant 
reglera vilka institutioner som ska användas vid placeringar. Det finns i alla kommuner en policy för hur ramavtalet ska hanteras och som också medger vissa avsteg från ramavtalet. ${ }^{5}$ Det är framför allt vid tre tillfällen som policyn tillåter vårdköp utanför avtalet (se Tabell 2). När platser inte kan erbjudas på en lämplig verksamhet som finns inom ramavtalet, när en speciell kompetens saknas hos de verksamheter som står till buds eller när särskilda arbetsmetoder önskas och som endast finns hos andra vårdgivare än dem man har avtal med. I de flesta fall medger inte policyn andra orsaker att gå utanför ramavtalet. En mellanställning har

5 Vi har frågat svarspersonerna om kommunens policy tillåter avsteg från ramavtalet enligt degrunder som presenterasi Tabell 2. Därefter har vi frågat om det skett i praktiken. Vi kan inte uttala oss om hur vanliga sådana avsteg är dock frågan om avstånd från hemmet. I var tredje kommun medger policyn att avsteg från ramavtalet kan ske för att antingen söka en institution som ligger långt borta eller nära kommunen. I var femte kommun

6 Det vi kallar infidelity-gap är helt enkelt skillnaden mellan hur dessa påståenden hanteras i praktiken och de uppfattningar som gäller enligt kommunens policy. Det handlar alltså om hur många kommuner som inte är trogna sin policy vad gäller skyldigheten att följa ramavtalet. Det är naturligtvis viktigt att poängtera att det som vi mätt som kommunens policy inte nödvändigtvis behöver överensstämma med själva ramavtalstexterna. Det handlar om våra intervjupersoners uppfattningar om vilka riktlinjer politiker och högre tjänstemän har givit vad gäller hur den köpta vården skall fungera i kommunen.

\section{Tabell 2.}

Möjligt och tillåtet att gå utanför ramavtalet enligt kommunens egen policy, uppgifter om hur det fungerar i praktiken, samt graden av avvikelse bland Sveriges kommuner och kommundelar (Stockholm, Göteborg och Malmö) som har ramavtal. N=227. Rangordnade enligt policy.

\begin{tabular}{lccc}
\hline Påstående & Enligt policy & I praktiken & Infidelity-gap $^{\mathbf{6}}$ \\
\hline Plats kan inte erbjudas & 92,9 & 99,1 & 6,2 \\
\hline Speciell kompetens saknas & 85,9 & 98,7 & 12,8 \\
Särskilda arbetsmetoder önskas & 85,8 & 99,1 & 13,3 \\
Rä̈t avstånd från hemmet & 32,3 & 79,6 & 47,3 \\
Önskemål från enskilde (brukare) & 19,5 & 79,2 & 59,7 \\
Likvärdig insats till lägre kostnad & 5,3 & 32,4 & 27,1 \\
Godtagbar vård till lägre kostnad & 4,9 & 32,3 & 27,4 \\
Vårdgivare visat goda resultat & 4,9 & 46,0 & 41,1 \\
Tidigare goda erfarenheter av samarbete & 4,9 & 46,5 & 41,6 \\
\hline
\end{tabular}

Torbjörn Forkby \& Staffan Höjer: Ritual eller strategi - upphandlingar.. 
medger kommunens policy att enskilda brukares önskemål kan vara en orsak till ett avsteg från avtalet. Övriga orsaker, t.ex. ekonomiska sådana medges endast av få.

I praktiken fungerar dock inte alltid kommunens policy, se Tabell 2. Så gott som samtliga kommuner tillämpar inte ramavtalet i praktiken om plats inte kan erbjudas samt om speciell kompetens saknas eller särskilda arbetsmetoder önskas. I praktiken kan också nästan åtta av tio kommuner komma att välja en verksamhet vid sidan av ramavtalet för att avståndet skall vara rätt från hemmet eller för att enskilda brukare har ett visst önskemål. Just vad gäller brukares önskemål har många kommunrepresentanter påpekat att så skulle kunna ske, men att det händer mycket sällan, mycket mer sällan än när de jämför med kommunernas missbruksvård. Även vårdgivares goda resultat eller tidigare goda erfarenheter av samarbete med olika vårdgivare är i nästan hälften av kommunerna orsak till avsteg från policyn. Lägst är avsteg kopplade till ekonomiska överväganden. Ändå medger representanter från cirka var tredje kommun att möjligheten att få en godtagbar eller likvärdig insats till lägre kostnad kan vara ett skäl att i praktiken kringgå avtalet. När det handlar om relationen mellan praktik och policy så framstår störst skillnader för fyra olika påståenden. Det handlar om önskemål från brukarna, rätt avstånd från hemmet, om vårdgivares goda resultat och om goda erfarenheter av samarbete.

Utfallet kan förstås som ett exempel på blandade styrlogiker. Ramavtalet kan ses som uttryck för en byråkratisk styrmodell. Denna motverkas av en professionell logik som t.ex. framhåller vikten av brukarinflytande eller det eventuella användandet av närhetsprincipen vid placering av ungdomar. Marknadslogiken betonar att finna rätt insats till lägst kostnad.

När Sveriges kommuner delas upp i tre ungefär lika stora delar baserat på vilka som följer respektive inte följer de egna ramavtalen, där en representerar de trogna, en normal-otrogna och en de mest otrogna, och vi kontrollerar för en mängd olika bakgrundsfaktorer, går det inte att hitta någon som på ett signifikant sätt utmärker sig för varför man är mer trogen eller otrogen sina ramavtal. Varken strukturella skilnader (kommuntyper, vilken politisk majoritet som gäller i kommunen, ohälsotal, andel ensamstående mödrar eller andel personer med utländsk bakgrund) administrativa förhållanden (antalet placeringar på institution, förekomst av egna vårdköpsmanualer) eller regleringsinställning (olika inställning till påståenden om ramavtalens nytta i Tabell 2) kan förklara varför en kommun är trogen sitt avtal eller inte. Kommuner som haft ramavtal under längre tid kunde dock göra avsteg från ramavtalen oftare för att få likvärdiga insatser till lägre kostnader än sådana som nyss infört dem.

\section{Alternativ till upphandlingar och ramavtal}

Ramavtal och upphandlingar är inte det enda sättet att styra över vårdköpen, och en ansenlig grupp av de intervjuade markerade att ramavtalen är missriktade och ett slag i luften. Man kan från ovan refererad forskning förvänta sig att alternativa styr- 
former växer fram riktade till det specifika området. Några sådana har också identifierats i undersökningen. Den första formen är en variant av ägarstyrning som följer av att kommunerna själva äger ett vårdbolag som socialtjänsten köper tjänster från. Man behöver inte upphandla vården i och med att den ges från det egna bolaget. Den andra formen är att avsätta interna controllers som ansvarar för förhandlingar, ibland anskaffning av institutioner och viss uppföljning. Den tredje formen är att man vid direktupphandlingar enbart tagit fasta på en del av vårdköpen och utvecklat ett eget avtalsunderlag för att komma ifrån att institutionerna äger rätten till att formulera avtalstexten.

Den fjärde formen som finns i ett mindre antal kommuner kan ses som ett kvalitativt annorlunda sätt att försöka styra vårdköpen. Här har man skapat särskilda hvb-samordnare som har ansvar för många frågor rörande vårdköp, i synnerhet sådana som rör relationen mellan köpare och utförare. Modellen går ut på att ett mindre antal institutioner väljs ut med vilka man har ett närmare samarbete. Relationen mellan köpare och utförare omdefinieras från att ses som motparter i en förhandling till att bli mer ömsesidigt beroende. Kommunens upphandlare har tilldelats en mer aktiv roll i att hålla sig uppdaterad med situationen såväl på institutionerna som inom förvaltningen. Kontinuerliga möten anordnas mellan kommun och institutioner för att kunna ge och ta information och etablera närmare och förtroendefulla relationer.

\section{Administrativt stöd och styrning vid vårdköp}

I undersökningen efterfrågades om man även vid andra frågor tog stöd från en specialiserad inköpsfunktion vid vårdköp, förutom vid upphandlingar av ramavtal. De kommuner som tog i anspråk ett sådant stöd mer frekvent och i fler frågor kunde antas ha utvecklat den administrativa styrningen mer, och därmed möjligen att managementtänkandet har ökad tyngd i förhållande till det individualiserade behovstänkandet. En fråga ställdes om man hade utvecklat andra instrument, manualer för vårdköpen. Tabell 3 visar att mellan 22 och 29 procent av kommunerna har andra utvecklade administrativa system än ramavtalet. Den visar också att det finns en signifikant skillnad mellan de kommuner som har ramavtal och de som saknar. I de kommuner som har ramavtal är vårdköpen också på andra sätt mer administrativt reglerade. Det finns också en signifikant skillnad i det att kommuner som har många placeringar totalt eller andelsmässigt har en mer omfattande administrativ reglering (framgår ej av tabellen).

\section{Diskussion}

Vi kan konstatera att införandet av ramavtal för köpt vård inom den sociala ungdomsvården har fått ett stort genomslag $\mathrm{i}$ Sveriges kommuner. Mer än sex av tio kommuner har ett sådant idag. Uppfattningarna om ramavtal är generellt sett positiva när det handlar om ramavtalens administrativa funktion, att skapa ordning och reda i upp- 
handlingarna av köpt vård. Inställningen är mer delad när det handlar om ramavtalens påverkan på kvaliteten. Alla kommuner som har ramavtal har också en policy som medger avsteg från ramavtalen. I många kommuner handlar det om när platser inte kan erbjudas eller när speciell kompetens saknas och särskilda arbetsmetoder önskas. I praktiken följs inte denna policy. Sammantaget är avstegen så stora att vi frågar oss vilken roll ramavtalen spelar för de individuella placeringarna. Vi har också sett att kommunerna använder andra former av styrning för att påverka den köpta vården. Skapandet av egna vårdbolag och införandet av interna controllers är ett par sådana styrformer.

I den avslutande texten vill vi diskutera tre frågor som varit centrala under denna del av forskningsprojektet; (i) hur relaterar uppfattningarna om ramavtalens funktioner till hanterandet av den köpta vården i kommunerna; (ii) i vilken mån fungerar ramavtal som ett styrinstrument för kommunerna vad gäller den köpta vården för ungdomar; samt (iii) hur skall vi se på ramavtalens roll för hur den enskilda köpta vården faktiskt kommer att utformas?

\section{Uppfattningarom ramavtalen}

De som hade ramavtal var också klart mer positiva till dem än de som saknade sådana. Detta skulle kunna förklaras av att uppfattningarna påverkat valet att införa ramavtal. Relationen mellan uppfattningar, attityder och faktiska omständigheter är dock vanligen mer komplicerad. Det finns en benägenhet att försvara sitt eget system och "gilla läget", vilket bland annat Svallfors (1996) diskuterat när det handlar om

\section{Tabell 3.}

Andel av centrala aktörer inom socialtjänstens barnavård $i$ Sveriges kommuner och kommundelar (Stockholm, Göteborg och Malmö) som menar att de tar stöd av specialiserad inköpsfunktion, eller har en lokal manual, i frågor om köpt vård för tonåringar. $N=336$. Fördelat efter förekomst av ramavtal.

\begin{tabular}{|c|c|c|c|c|}
\hline & \multicolumn{2}{|c|}{ Totalt } & \multirow{2}{*}{$\begin{array}{c}\begin{array}{c}\text { Har ram- } \\
\text { avtal }\end{array} \\
28,9\end{array}$} & \multirow{2}{*}{$\begin{array}{c}\begin{array}{c}\text { Saknar } \\
\text { ramavta }\end{array} \\
6,4\end{array}$} \\
\hline Spec funkt - vid enskilda placeringsavtal & 21,6 & ***** & & \\
\hline $\begin{array}{l}\text { Spec funkt - uppföljning, kontroll, utvärdering, tvister } \\
\text { och liknande }\end{array}$ & 22,6 & ******* & 28,3 & 10,0 \\
\hline Har manual för vårdköp & 28,6 & ****** & 34,8 & 15,6 \\
\hline
\end{tabular}

Signifikansnivå (p). ${ }^{* * *} \mathrm{p} \leq 0.001,{ }^{* *} \mathrm{p} \leq 0,01,{ }^{*} \mathrm{p} \leq 0,05$, n.s. $=$ ej signifikant 
attityder i välfärdsfrågor. Det skulle kunna vara så att de kommuner där ledande tjänstemän är positiva till ramavtal i högre utsträckning går in i upphandlingsprocesser. Samtidigt påverkar förekomsten av ramavtal i sin tur inställningen. Man lär sig hur ramavtalet fungerar och hittar sätt att manövrera under det gällande systemet. Vi anar alltså ett samspel där en viss positiv attityd i förväg förstärks när man sätter sig in i systemet och tvärtom att en negativ inställning förstärks när man står vid sidan om. Men ytterligare en läroprocess antyds i materialet. Visserligen var de som hade ramavtal mer positiva till sådana system, men detta gällde främst för dem där ramavtal införts ganska nyligen. De andra var mer tveksamma. Att "gilla läget» kan i denna mening innebära en läroprocess där man först rycks med och hoppas att upphandlingssystemen ska tillföra mer rationalitet och kontroll av processerna. I det praktiska arbetet blir dessa förhoppningar konfronterade med andra styrlogiker (och den krassa verkligheten), varvid anpassningsstrategier utvecklas.

Väl att märka är att vi endast undersökt attityderna hos enstaka strategiska chefstjänstemän inom den sociala barnavården i varje kommun och vet inte något om i vilken utsträckning dessa åsikter är representativa för andra viktiga aktörer, t.ex. politiker, socialsekreterare, brukare och vårdgivare. ${ }^{7}$ Sammantaget verkar det dock som om attityder till ramavtal kan spela en

7 Annan forskning har visat att det finns en betydande ambivalens inom socionomprofessionen till privatiseringar (Dellgran \& Höjer 2003, 2005, Liljegren et al. 2008) viss roll för om man har ett ramavtal eller inte, men ingen eller mycket liten roll för om man sedan följer avtalet.

\section{Ramavtalen som styrinstrument}

Styrförutsättningar och problem inom hälso- och sjukvården, diskuteras av Berlin (2006). Relationen mellan beställare och utförare är paradoxal, i ena stunden är den antagonistisk där båda parter kalkylerar för att uppnå största möjliga egennytta. Information är en hårdvaluta i deras relation. En god kunskap om arbetsprocessen erbjuder exempelvis större möjlighet till styrning från beställarens sida. I andra stunden är parterna beroende av varandra och utvecklar också relationer som går utöver de rent marknadsmässigt ekonomiska. Beställarstyrning är en komplex och avancerad styrform som utlovar stora vinster ekonomiskt och effektivitetsmässigt, men i praktiken fungerar beställarstyrningen i bästa fall "på marginalen«. Förhandlingen sker om sista procenten i anslaget ska dras ifrån eller läggas till, inte om själva basverksamheten.

Vårt område har såväl likheter som olikheter i förhållande till hälso- och sjukvårdens beställarstyrning. Likheten är spänningen och de dubbla relationerna mellan köpare och säljare (beställare och utförare). Likheten är också den marknadsideologi som ligger bakom båda systemen. Olikheten ligger främst i vad man förhandlar om. Inom hälso- och sjukvården är det konkreta kvantiteter som fastställs och beställs där det ofta enbart finns en enda möjlig utförare, åtminstone när det gäller den specia- 
liserade vården. Inom den sociala barn- och ungdomsvården finns ibland fler vårdgivare att tillgå och samtidigt en större osäkerhet om vilken typ av vård man önskar att köpa. Den sociala ungdomsvården är ett mycket mer lösligt system där vardera parten först binds samman när konkreta vårdköp görs. Att systemet är så lite förpliktigande kan vara ett skäl till att det uppfattas som lamt bland flera. Det är därför följdenligt att vi också funnit att system utvecklats för (hybrid)styrning (Williamsson 1996) som utgår från närmare och ömsesidiga relationer och öppnare och mer ömsesidig information.

\section{Rituell marginalstyrning och blandade styrlogiker}

Som framgår av studien så var det främst de administrativa aspekterna som uppfattades ha fått en bättre reglering, exempelvis nämndes uppsägningstiderna. När det gäller styrningen av kostnader eller kvalitet framkommer en mycket större tveksamhet. Exempelvis blir ramavtalet som ekonomiskt styrinstrument klart begränsat då det uppfattas ha mycket liten effekt på vårddygnskostnaden. Även om regleringen av uppsägningstider också har en ekonomisk dimension, blir den tämligen uddlös om en högre risk för institutionerna genom kortare uppsägningstider kompenseras av högre dygnsavgift. När det gäller kvalitetsfrågorna framkom ännu större tveksamhet. Möjligen kan upphandlingsprocessen höja den lägsta kvalitetsnivån när avtalen sluts. Men vad som händer därefter och framförallt hur det inre livet på institutionen fungerar är mycket svårare att få inblick i (jfr. Forkby 2005). De resultat som hittills verkar ha uppnåtts kan uppfattas som ringa i förhållande till ambitionerna, så varför håller man då på?

Ett första svar kan vara att man uppfattar att lagstiftningen kräver att dessa tjänster ska upphandlas, vare sig man bedömer det riktigt eller inte. Detta svar omfattar uppenbarligen inte alla kommuner i undersökningen. Ett andra svar är att upphandlingar och upprättandet av affärsmässiga relationer trots allt är ett ganska nytt fenomen vilket tar tid att lära sig. Värdet med upphandlingarna bör därför inte i första hand avläsas i dess kapacitet att styra, utan i de förhoppningar om att kunna styra som skapas i processen. Just genom att få tillfälle att artikulera kvalitetskriterier och genom att parterna under upphandlingsprocessen tvingas inta mer affärsliknande relationer till varandra, har upphandlingarna en så stor formlikhet med "traditionella" marknadsrelationer att systemet kan sägas utställa löften. För att infria dessa måste dock upphandlingssystem utvecklas och förfinas för att bättre motsvara förutsättningarna inom den sociala barnavården. Det vi ser idag kan i så fall ses som en läroprocess, även om denna tolkning delvis motsägs av det faktum att kommuner med längre erfarenhet av ramavtalen var mer skeptiska än de som nyss infört dem.

Ett tredje svar är att intresset för upphandlingar och ramavtal kan förstås genom att dessa uppfyller delvis andra funktioner än de uttalade. Vi skulle här kunna tala om upphandlingsinstitutionen inom detta område som rituell mar- 
ginalstyrning. Den är rituell eftersom den följer vissa mönster som uppfattas moderna, riktiga och i linje med ett ökat managementtänkande inom offentlig verksamhet. Den är en styrning på marginalen eftersom det som den faktiskt har förmåga att styra över handlar om den sista »hundralappen", inte om tjänsternas kärna. Att tala om upphandlingarna som ritualer som moderna organisationer följer för tankarna till nyinstitutionell teoribildning som bland annat lyfter fram legitimitetsstrategier och lösa kopplingar mellan institutionell och operativ nivå (Powell \& DiMaggio 1991, Scott \& Meyer 1994). I denna mening kan upphandlingarna ses som system som stärker organisationens legitimitet utåt i och med att den visar att den anammat hur rationella moderna styrsystem bör se ut. Detta betyder dock inte att styrningen i praktiken måste bli särskilt ingripande på den operativa nivån. Den dagliga verksamheten och de legitimitetsbevakande nivåerna fungerar nämligen enligt skilda logiker och har enbart lösa kopplingar (Weick 1976).

Brunsson (2006a, b) talar om en organisation av hyckleri (organization of hypocrisy) där det ofta föreligger en skillnad mellan talet om insatser, beslutet om dem och de faktiska insatserna. Ramavtalen är legitimerande för kommunerna och kan sägas uppfylla flera, i vissa fall motstridiga, mål samtidigt. De förtydligar och klargör den administrativa och legala hanteringen av vårdköpen och inordnar dessa enligt lagen om offentlig upphandling. De söker upprätthålla tanken om att den ekonomiskt mest fördelaktiga behandlingen skall väljas. Samtidigt betonas kvalitetskriterier och vikten av att anpassa valet av behandling till den enskilda ungdomens situation. Detta understryker hur blandade styrlogiker opererar inom skapandet av ramavtal inom den sociala ungdomsvården. Kanske är det som rituell marginalstyrning ramavtalen spelar störst roll idag. Det faktum att relationerna mellan kommuner och vårdgivare uppfattas regleras i avtal ger vårdköpen en viktig legitimitet.

Verksamheten i människovårdande organisationer måste ha kapacitet att hantera en komplexitet i vardagliga möten. Att arbeta med ungdomar i svåra livssituationer handlar om att kunna hantera och förhandla med många olika intressen och hitta insatser under stor osäkerhet om vad som är bäst att göra. Ett sådant arbete kräver ett stort mått av frihet för att kunna agera flexibelt i situationen (Lipsky 1980), inte minst till den officiella versionen av hur arbetet bedrivs. Arbetet kräver också tillitsfulla relationer som kan hantera de påfrestningar som uppstår. Mycket talar för att sådana etablerade allianser mellan köpare och säljare har stor betydelse för vilka nya avtal som sluts. På denna vårdmarknad är det troligt att köpen till stor del avgörs genom förhandlingar i nätverk av sociala relationer. I förhandlingarna spelar aktörernas olika föreställningar om vårdens kvalitet en stor roll, samt vilket förtroende en vårdgivare har, vilka rykten som sprids om den och vilken status den tillägnas (Bradach \& Eccles 1991). För att kunna gå djupare in på dessa frågor krävs dock en närstudie av hur de individuella vårdavtalen sluts och vilka motiv och behov för placering som presenteras i underlag till beslut. 


\section{Referenser}

Almqvist, R. (2006) New Public Management om konkurrrenssättning, kontrakt och kontroll. Stockholm: Liber.

Andreassen, T. (2003) Institutionsbehandling av ungdomar. Vad säger forskningen? Stockholm: Gothia.

Berlin, J. (2006) Beställarstyrning av hälso- och sjukvård: om människor, marginaler och miljoner. Göteborg: Göteborgs universitet, Förvaltningshögskolan.

Blom, B. (1998) Marknadsorientering av socialtjänstens individ- och familjeomsorg: om villkor, processer och konsekvenser. Umeå: Umeå universitet.

Bradach, J.L. \& Eccles, R.G. (1991) "Price, authority and trust: from ideal types to plural Forms». I G. Thompson, J. Francis, R. Levacic \& J. Mitchell (eds.) Markets, hierarchies and networks: The coordination of social life. London: Sage.

Brunsson, N. (2006a) The Organization of Hypocrisy. Talk, Decisions and Actions in Organizations. Malmö: Liber.

Brunsson, N. (2006b) Mechanisms of Hope. Maintaining the Dream of the Rational Organization. Malmö: Liber.

Callon, M. (1998) „An essay on framing and overflowing: economic externatlities revisted by sociology». I M. Callon (ed.) The laws of the market. Oxford: Blackwell Publishers.

Dellgran, P. \& Höjer, S. (2003) „En delad och ambivalent profession. Socionomers attityder till privatisering av socialt arbete." Socionomens forskningssupplement 15, s. 17-36.

Dellgran, P. \& Höjer, S. (2005) „Privatisation as professionalisation. Attitudes motives and achievements among Swedish social workers." European Journal of Social Work Vol 8 No 1, pp. 41-64.

Evans, T. \& Harris, J. (2004) „Street-level bureaucracy, social work and the (exaggerated) death of discretion." Brititsh Journal of Social Work 34 (6), pp. 871-895.

Fargion, S. (2003) "Images of Contract. An Empiri- cal Study of the Use of Theory in Practice." British Journal of Social Work 33, pp. 517-533.

Forkby, T. (2005) Ungdomsvård på hemmaplan. Idéerna, framväxten, praktiken. Göteborg: Göteborgs universitet.

Freidson, E. (2001) Professionalism: the third logic. Cambridge: Polity Press.

Hasenfeld, Y. (1983) Human Service Organizations. Englewoods Cliffs: Prentice Hall.

Hasenfeld, Y. \& Powell, L. E. (2004) »The role of Non-profit Agencies in the Provision of Welfare-to Work Services." Administration in Social Work 28, pp. 91-110.

Johansson, T. (2006) Förvaltningens gräns mot marknaden: om mekanismer bakom och effekter av kommunernas marknadsutnyttjande. Göteborg: Göteborgs universitet, Förvaltningshögskolan.

Kirkpatrick I, Kitchener M, Owen D \& Whipp R (1999) „Un-charted Territory? Experiences of the Purchaser/Provider Split in Local Authority Children's Services." British Journal of Social Work 29, pp. 707-726.

Kvale, S. (1997) Den kvalitativa forskningsintervjun. Lund: Studentlitteratur.

Levin, C. (1998) Uppfostringsanstalten om tvång $i$ föräldrars ställe. Lund: Lunds universitet.

Liljegren A, Dellgran P \& Höjer S (2008) „Between ideology and pragmatics - Social worker's unions in an era of privatization." European Journal of Social Work. Accepted for publication.

Lipsey, M.W. (1995) "What do we learn from 400 Research Studies on the Effectiveness of Treatment with Juvinile Delingquents?". In McGuire \& Pristley What Works: Reducing Reoffending - Guidelines from Research and Practice. Chichester: Wiley.

Lipsky, M. (1980) Street level bureaucracy-Dilemmas of the Individual in Public services. New York: Sage.

Lundström, T. \& Svedberg, L. (1998) „Svensk frivillighet i internationell belysning - en Inledning." Socialvetenskaplig tidskrift $5 \mathrm{nr}$ 2-3, s.106-127. 
Lundström, T. \& Vinnerljung, B. (2001) »Omhändertagande av barn under 1990-talet». I M. Szebehely (red.) SoU 2001:52. Välfärdstjänster i omvandling, forskarantologi frän Välfärdsbokslutet. Stockholm: Fritzes.

Montin, S. (1996) Förnyelse av kommuner och landsting: slutbetänkande. Bil. 5, Förändringsmodeller och förändringsprocesser $i$ kommuner och landsting: några empiriska studier. Stockholm: Fritzes.

Norén, L. (2003) Valfrihet till varje pris: om design av kundvalsmarknader inom skola och omsorg. Göteborg: BAS.

Ohlsson, L.B. (2007) Utvärdering av Skånes kommuners gemensamma upphandling av vård inom Individ och familj. Utvärderingsrapport. Lund.

Ouchi, W.G. (1977) »The Relationship Between Organizational Structure and Organizational Control.» Administrative Science Quarterly. Vol 22 Issue 1, s. 95-113.

Pollitt, C. \& Bouckaert, G. (2000) Public management reform a comparative analysis. Oxford: Oxford University Press.

Powell, W. \& DiMaggio, P. (1991) The new institutionalism in organizational analysis. Chicago: University of Chicago Press.

Sallnäs, M. (2000) Barnavårdens institutioner: framväxt, ideologi och struktur. Stockholm: Stockholms universitet.
Sallnäs, M. (2005) „Vårdmarknad med svårigheter - om privata aktörer inom institutionsvården för barn och ungdomar." Socialvetenskaplig tidskrift 12(2-3), s. 226-246.

Salomon, L. (red.) (2002) The State of Nonprofit America. Washington DC: Brookings institution press.

Scott, W. R. \& Meyer, J. W. (1994) Institutional Environments and Organizations. London: Sage.

Selle, P. (1996) Frivillige organisasjoner $i$ nye omgjevnader. Bergen: Alma Mater.

Socialstyrelsen (2006) Social rapport. Stockholm: Fritzes.

Socialstyrelsen (2007a) Jämförelsetal för socialtjänsten år 2006. Nedladdad www.socialstyrelsen.se 2008-02-04

Socialstyrelsen (2007b) Barn och unga - insatser år 2006. 2007:9. Stockholm: Fritzes.

Svallfors, S. (1996) Välfärdsstatens moraliska ekonomi. Välfärdsopinionen $i$ 90-talets Sverige. Umeå: Borea.

Weick, K. (1976) »Educational Organization as Loosely Coupled Systems." Administrative Science Quartely, 21, pp. 1 - 19.

Wiklund, S. (2006) Den kommunala barnavairden: om anmälningar, organisation och utfall. Stockholm: Stockholms universitet.

Williamson, O.E. (1996) The mechanisms of governance. New York: Oxford University Press.

\section{Summary}

\section{Rituals or strategy \\ Contracting and general agreements within child welfare}

In child welfare cases when young people are placed in treatment institutions, there is often a tension between economic and treatment-oriented rationalities. The aim of this article is to analyse what relevance the introduction of new forms of gover-

Torbjörn Forkby \& Staffan Höjer: Ritual eller strategi - upphandlingar.. 
nance in Swedish child welfare have had on the choice of placements for children at risk. The following questions are discussed: (1) To what extent have Swedish municipalities introduced general agreements for purchasing of treatment institutions? (2) What are the perceived advantages and disadvantages of these general agreements? (3) To what extent are the general agreements followed by local policy and practice? The methods used in this study have been telephone interviews with managers of child welfare at social services in all Swedish municipalities $(n=336)$. The results indicate that more than half of all Swedish municipalities have adapted to the general agreements for purchasing treatment institutions. The attitudes towards the level of governance differ, as people point to administrative advantages but disadvantages when it comes to making good matches in the individual cases. However, in the individual cases a great deal of disobedience of the administrative agreements has been experienced. In the discussion it is questioned whether this is an example of ritual governance in order to create legitimacy. 